\title{
THE EFFECT OF COST CONTROL EFFECTIVENESS AND WORKING CAPITAL TURNOVER ON FIRM VALUE IN THE FOOD AND BEVERAGE SECTOR LISTED ON THE INDONESIA STOCK EXCHANGE
}

\author{
Alfian Nur Rahim ${ }^{1^{*}}$ \\ Faculty of Economics, Universitas Sarjanawiyata Tamansiswa, Yogyakarta \\ E-mail: ${ }^{1)}$ alfiannoski@gmail.com
}

\begin{abstract}
This study aims to examine and analyze the Effect of Cost Control Effectiveness and Working Capital Turnover on Firm Value as an intervening variable. The sample used in this study is secondary data taken from the Indonesia Stock Exchange with 11 companies in 2011 - 2018. The hypothesis is tested using multiple linear regression. The sample used in this research is purposive sampling technique, classical assumption test consisting of normality test, multicollinearity test, heteroscedasticity test, multiple linear regression test consisting of hypothesis testing, determination test and to prove the research hypothesis. The results of this study indicate that the Effectiveness of Cost Control (EPB) has a negative and significant effect on firm value. Working Capital Turnover (PMK) has a positive and significant effect on firm value. Moreover, the Effectiveness of Cost Control and Working Capital Turnover simultaneously has a positive and significant effect on Firm Value.
\end{abstract}

Keywords: Cost Control Effectiveness, Working Capital Turnover and Firm Value.

\section{INTRODUCTION}

One of the business sectors that continues to grow is the food and beverage industry. The volume of demand for Food and Beverage in Indonesia continues to rise in alongside with the country's growing population. The Indonesian people's preference for ready-to-eat food has resulted in the emergence of a slew of new food and beverage businesses. As a response, business competition is becoming more intense. Companies must reinforce their basics in order to compete with other similar companies in this increasingly intense competition. When a company is unable to compete with global companies, it will see a decline in volume, eventually leading to insolvency. Furthermore, recent business advances necessitate that business players respond more quickly to any changes that occur in today's competitive business environment.

It is critical for a firm to maximize its value, as it entails increasing the organization's primary objective. Increasing the company's worth is a goal that the owners have set for themselves, as it will improve their financial well-being in the long term. In addition, the food and beverage industry is expanding in Indonesia because almost everyone has to eat and drink at some point in their lives. Apart from that, stocks in food and beverage subsector companies are the most resilient to the current financial crisis of any sector or subsector, because food and beverage products will always be in demand, crisis or no crisis. 
Based on this fact, the food and beverage sub-sector companies will continue to survive. It is predicted that many factors will influence firm value, two of which are cost control effectiveness and working capital turnover. The effect of cost control effectiveness and working capital turnover is theoretically explained in more detail in the theories. Thus, researchers use both variables, namely the effectiveness of cost control and working capital turnover as independent variables to prove their effect on the value of companies projected or measured using PER (Price Earning Ratio) as dependent variables.

\section{THEORY REVIEW}

\subsection{Cost Control Effectiveness}

Relating the effectiveness, researcher will express his opinions based on expressed understanding by experts. The first opinion, namely the opinion expressed by Makmur (2013) reveals effectiveness related to the level of truth or error. He argues that to determine the level of effectiveness of the success of a person, group, organization, we must make a comparison between the truth or accuracy with the error or what will be done. The lower the level of errors or errors that occur, of course, the closer the accuracy in carrying out the activities or work (tasks) that are charged.

Another opinion expressed by Lukman Dendawijaya (2013) states that the effectiveness of cost control is a condition where the company is able to realize the goals that have been set in an effectiveness value that starts from how the company runs a control, while the opinion expressed by Sedarmayanti (2016) states that effectiveness as a measure that provides an overview how far the target can be achieved. This understanding of effectiveness is output-oriented, while the problem of using less input will be a major concern. The effectiveness of cost control is measured by the BOPO ratio, namely by comparing operational costs with operating income. The formula for cost control efficiency with the BOPO ratio is as follows:

$$
\mathrm{BOPO}=\frac{\text { operating costs }}{\text { Operating income }} \times 100 \%
$$

The relationship between the measurement of cost control using the BOPO ratio level and the cost control methods proposed by Mulyadi (2013) is that the correct measurement is more on the standard full costing system which states the planned costs to be allocated with a real activity plan, while the BOPO ratio is only as a measurement level only.

\subsection{Working Capital Turnover}

Every company needs to provide working capital. Companies engaged in any field, both service companies and production companies will always need working capital to finance their production business in the hope that the funds that have been spent can return to the company in a relatively short term. To assess the effectiveness of working capital, the sales ratio divided by current assets minus current liabilities. And the opinion expressed by Kasmir (2018) states that the ratio to measure the level of working capital turnover can be formulated as follows: 


\section{JOURNAL OF MANAGEMENT, ACCOUNTING, GENERAL FINANCE AND INTERNATIONAL ECONOMIC ISSUES \\ (MARGINAL) \\ VOLUME 1 ISSUE 1 (2021)}

$$
\text { Working Capital Turnover }: \frac{\text { Sales }}{\text { Current assets - Current liabilities }}
$$

Based on the explanation above, it can be explained that the measuring instrument for calculating working capital turnover is formulated as sales divided by current assets minus current liabilities in the company's financial statements.

\subsection{The Value of the Company}

Firm value is an investor's perception of the company's level of success which is often associated with stock prices. High stock prices make the value of the company also high. A high company value will make investors believe, not only in the company's current performance, but also in the company's prospects in the future, so that there is a desire for investors to invest in the company. In addition, with a high company value, the prosperity of the shareholders also increases, so that the company's main goals are achieved. For investors, the higher the Price Earning Ratio, the expected profit growth will also increase. Thus, the Price Earning Ratio (the ratio of price to profit) is the comparison between market price per share and earnings per share. Further, Irwan Djaja (2017) argues that the formula for calculating Price Earning Ratio (PER) is as follows:

\section{$\mathrm{PER}=$ Market Price per Share / Earning per Share}

\subsection{Research Hypothesis}

1. Simultaneous Hypothesis:

a. There is an effect of Cost Control Effectiveness and Working Capital Turnover on Firm Value.

2. Partial Hypothesis.

a. There is an effect of Cost Control Effectiveness on Firm Value.

b. There is an effect of Working Capital Turnover on Firm Value. 


\subsection{Framework of thinking}

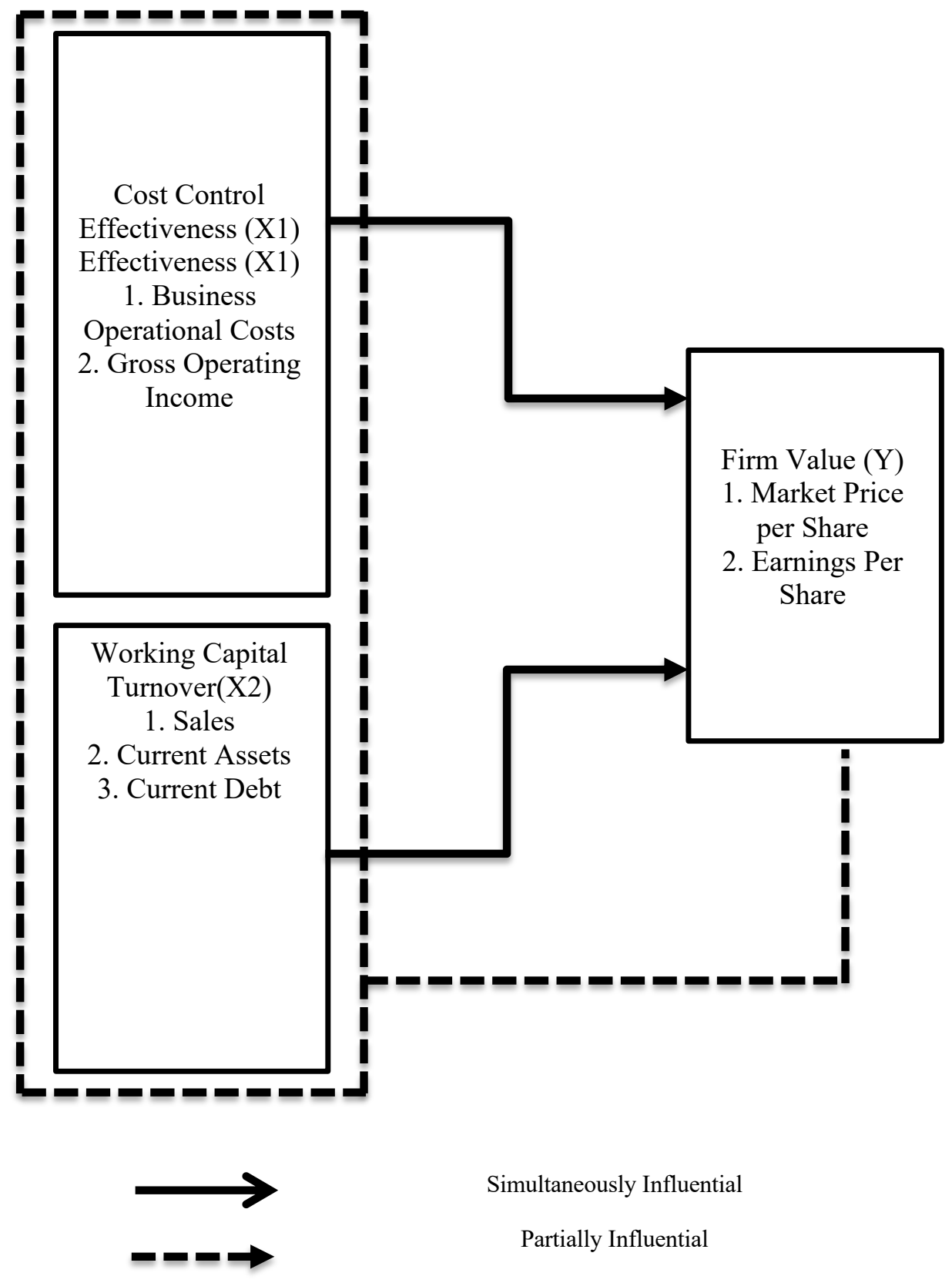

Figure 1 Framework of Thinking

\section{RESEARCH METHODS}

This study uses descriptive research methods proposed by Sugiyono (2013) that descriptive research methods are research conducted to determine the value of independent variables, either one or more variables without making comparisons, or connecting with other variables. Descriptive method used to determine the condition of the effectiveness of cost control and working capital turnover and firm value. 


\section{JOURNAL OF MANAGEMENT, ACCOUNTING, GENERAL FINANCE AND INTERNATIONAL ECONOMIC ISSUES \\ (MARGINAL) \\ VOLUME 1 ISSUE 1 (2021)}

This study uses a verification method which aims to determine the relationship between two or more variables, as well as the method used to test the truth of a hypothesis, so that evidence can be taken that shows the hypothesis is accepted or rejected. In this study, the verification method used to answer questions in the formulation of the problem of how much influence the effectiveness of cost control and working capital turnover on firm value either simultaneously or partially.

\section{RESULTS AND DISCUSSION}

\subsection{Descriptive Statistical Analysis}

Table 1 Statistical Descriptive Analysis

\begin{tabular}{llllll}
\hline & N & Minimum & Maximum & mean & $\begin{array}{l}\text { Std. } \\
\text { Deviation }\end{array}$ \\
\hline EPB & 87 & .120 & 5.088 & .17423 & .543802 \\
PMK & 87 & .459 & 6.892 & 2.47346 & 1.559423 \\
PER & 87 & 27.00 & 75.70 & 17.3253 & 16.76695 \\
Valid N (listwise) & 87 & & & & \\
\hline
\end{tabular}

Source: Data processed by SPSS 16

Based on table 1, it can be seen that the statistical test results for the minimum, maximum, mean and standard deviation values with a total sample of 87 companies. The explanation of the results is as follows:

1) The variable of Cost Control Effectiveness shown by the EPB proxy has a value of minimum of 0.120 ; maximum value 5.088; mean value 0.17423 ; and has a standard deviation of 0.543802 .

2) Working Capital Turnover variable shown by the PMK proxy has a value of minimum of 0.459 ; maximum value 6,892 ; mean value 2.47346 ; and has a standard deviation of 1.559423 .

3) The Firm Value variable indicated by the PER proxy has a minimum value of 27; maximum value of 75.70; mean value 17.3253; and has a standard deviation of 16.76695 .

\subsection{Multiple Linear Regression Analysis}

The analysis in this study uses multiple linear regression with SPSS 16 software. Based on the output of SPSS 16 software, the influence of 2 independent variables, namely Effectiveness of Cost Control and Working Capital Turnover affects the dependent variable, namely Firm Value which can be seen in Table 2 along with the explanation:

Table 2 Multiple Linear Regression Analysis Results

\begin{tabular}{|c|c|c|c|c|c|}
\hline \multirow[b]{2}{*}{ Model } & \multicolumn{2}{|c|}{$\begin{array}{l}\text { Unstandardized } \\
\text { Coefficients }\end{array}$} & \multirow{2}{*}{$\begin{array}{c}\begin{array}{c}\text { Standardized } \\
\text { Coefficients }\end{array} \\
\text { Beta }\end{array}$} & \multirow[b]{2}{*}{$\mathbf{t}$} & \multirow[b]{2}{*}{ Sig. } \\
\hline & $\mathrm{B}$ & Std. Error & & & \\
\hline (Constant) & 0.859 & 3,507 & & 5,292 & .000 \\
\hline PMK & .627 & 1.172 & .058 & .535 & .044 \\
\hline EPB & .088 & 3.362 & .059 & .541 & .030 \\
\hline
\end{tabular}


Based on table 2, the test uses the multiple linear regression method to test the effect of the independent variables, namely Working Capital Turnover (PMK) and Cost Control Effectiveness (EPB) on the dependent variable Price Earning Ratio (PER) can be written with multiple linear regression equations as follows:

$$
\boldsymbol{P E R}=0.859+0.627 \mathrm{PMK}+0.088 \mathrm{EPB}
$$

While Multiple linear regression equation can be explained as follows:

a. The constant value of 0.859 indicates that the independent variable Working Capital Turnover (X1) and Cost Control Effectiveness (X2) are equal to zero, so the value of discretionary accruals Price Earning Ratio is 0.859 .

b. The Working Capital Turnover (PMK) variable shows that the value of Positive regression coefficient of 0.627 this indicates that PMK has a positive effect on firm value (PER). This shows that if the PMK variable which has an increase of $1 \%$ resulted in an increase in PER of 0.627 , with the assumption that other variables are considered constant.

c. The Profit Margin (EPB) variable shows that the coefficient value of positive regression of 0.088 this indicates that the EPB positive effect on firm value (PER). As a result, it is shows that if the EPB variable increases by $1 \%$ resulting in an increase in the Price Earning Ratio of 0.088 , with the assumption that other variables are considered constant.

\subsection{Classical Assumption Test}

The following will present the results of testing the classical assumptions on the regression model. This test is used to see whether the specification of the regression model used is correct or not. The basic tests in this study using classical assumption deviations include the normality test which is carried out through the Kolmogrov Smirnov test to determine whether the data used are normally distributed or not, autocorrelation test using run test values, multicollinearity test using Variance Inflation Factor (VIF), and Heteroscedasticity using the spearman test method.

\section{1) Normality Test}

Table 3 Results of Normality Test Analysis

\begin{tabular}{ll}
\hline asymp. Sig. (2-tailed) & 357 \\
Source: Data processed by SPSS 16
\end{tabular}

Normality test was conducted to see whether a regression model was normally distributed or not. Testing for normality in this study uses the Kolmogrov Smirnov test. If the significant value is above a certain significance, it can be concluded that the data is normally distributed with a significant level of 0.05 . Table 3 shows that the results of the normality test using the Kolmogrov Smirnov test, the Asymp.Sig value, shows a value of 0.357 above 0.05 , this indicates that the data in this study are normally distributed.

2) Autocorrelation Test

Table 4 Autocorrelation Analysis Results

asymp. Sig. (2-tailed) $\quad .064$




\section{JOURNAL OF MANAGEMENT, ACCOUNTING, GENERAL FINANCE AND INTERNATIONAL ECONOMIC ISSUES (MARGINAL) \\ VOLUME 1 ISSUE 1 (2021)}

Source: Data processed by SPSS 16

The autocorrelation test aims to test in the linear regression model whether there is a correlation between the confounding error in period $t$ and the confounding error in period $t$ 1 (previous). This autocorrelation test uses the Runs test to detect whether there is autocorrelation or not. A good regression model that does not contain symptoms of autocorrelation. Symptoms of autocorrelation can be detected if the Asymp. Sig value is below 0.05. Based on table 4, Runs test results of 0.64, this value is above the Asymp.Sig standard, so it can be concluded that the linear regression model does not occur autocorrelation.

\section{3) Multicollinearity Test}

Table 5 Multicollinearity Test

\begin{tabular}{lll}
\hline Model & $\begin{array}{l}\text { Collinearity Statistics } \\
\text { Tolerance }\end{array}$ & VIF \\
\hline (Constant) & & \\
EPB & .994 & 1.006 \\
PMK & .994 & 1.006 \\
\hline
\end{tabular}

Source: Data processed by SPSS 16

The multicollinearity test aims to test whether there is a correlation between the independent variables in linear regression. Tests using this regression model can be seen from the value of VIF (Variance Inflation Factor). Based on table 5 the VIF value of Cost Control Effectiveness (EPB) and Working Capital Turnover (PMK) has a VIF value that is far below 10, so it can be concluded that this regression model does not occur multicollinearity between independent variables.

4) Heteroscedasticity Test

Table 6 Results of Heteroscedasticity Test Analysis

Sig. (2-tailed)

\begin{tabular}{ll}
\hline EPB & .091 \\
PMK & .412 \\
\hline
\end{tabular}

Source: Data processed by SPSS 16

The heteroscedasticity test aims to test whether in a regression model there is an inequality of variance from the residual of one observation to another observation. This test is carried out using the Spearman test method. Based on table 6, the regression results show that all independent variables have insignificant values marked by the probability value $>$ 0.05 so it can be concluded that in this regression there are no symptoms of heteroscedasticity.

\subsection{Partial Hypothesis Testing (t-Test)}


Hypothesis testing with $t$ test is used to show the individual influence between the independent variables on the dependent variable. The results of hypothesis testing multiple regression linear analysis on each independent variable can be explained as follows:

a) Working Capital Turnover Variable (H1)

The first hypothesis proposed states that working capital turnover using a proxy (PMK) has a positive and significant effect on the Price Earning Ratio (PER). Based on the evaluation, the Beta Value is Not Equal to 0, which means that there is an Effect of Working Capital Turnover Variable and the probability value of the research results is 0.044 which is smaller than the predetermined significant level of 0.05 , then $\mathrm{H} 1$ is accepted, namely there is an influence between PMK on PER. Furthermore, the regression coefficient of the Working Capital Turnover variable on the Price Earning Ratio is 0.627 , which means it is positive. Every $1 \%$ increase in PMK will increase PER by $62 \%$ so that the results of testing the first hypothesis can be concluded that Working Capital Turnover has a positive and significant effect on Price Earning Ratio is accepted, then the first hypothesis is supported.

b) Cost Control Effectiveness Variable (H2)

The second hypothesis proposed states that the Effectiveness of Cost Control using a proxy (EPB) has a positive effect on Firm Value with a proxy (PER). Based on the evaluation, the Beta Value is Not Equal to 0, which means that there is an Effect of Variable Effectiveness of Cost Control and Probability of the research results of 0.030 which is smaller than the predetermined significant level of 0.05 then $\mathrm{H} 2$ is accepted, namely there is an influence between EPB on PER. Furthermore, the regression coefficient of the Cost Control Effectiveness variable on firm value is 0.088 , which means it is positive. Every $1 \%$ increase in EPB will increase PER by $8.8 \%$ so that the results of testing the second hypothesis can be concluded that Cost Control Effectiveness has a positive and significant effect on Firm Value is accepted, then the second hypothesis is supported.

\subsection{Simultaneous Hypothesis Testing (F-test)}

Hypothesis testing with the F test is used to show whether there is an effect of all the independent variables in this regression model having a joint effect on the dependent variable. The following can be seen in the table of $\mathrm{F}$ test results below:

Table 7 Results of F-Test Analysis

\begin{tabular}{llll}
\hline Model & & F & Sig. \\
\hline 1 & Regression & 2.268 & $.00^{\mathrm{a}}$ \\
& $\begin{array}{l}\text { Residual } \\
\text { Total }\end{array}$ & & \\
& & \\
\hline
\end{tabular}

Source: Data processed by SPSS 16

Based on the research table above, the results of the $\mathrm{F}$ test indicate that the significant value of 0.000 is smaller than the predetermined significant level of 0.05 which means that there is a simultaneous significant effect between the independent variable and the dependent variable, so the results of this study can be concluded that all variables independent, namely the Effectiveness of Cost Control and Working Capital Turnover which together affect the Company Value. 


\section{JOURNAL OF MANAGEMENT, ACCOUNTING, GENERAL FINANCE AND INTERNATIONAL ECONOMIC ISSUES (MARGINAL) \\ VOLUME 1 ISSUE 1 (2021)}

\subsection{Testing the Coefficient of Determination (R2)}

Testing the coefficient of determination can be used to measure how far the model's ability to explain variance dependent variable. The following table shows the results of multiple regression analysis testing:

Table 8 Analysis Results of Adjusted R Square

\begin{tabular}{l} 
Adjusted R Square \\
\hline .29 \\
Source: Data processed by SPSS 16
\end{tabular}

Based on research table above, it shows that the result of the adjusted $\mathrm{R}$ square is 0.29 or $29 \%$, this means $29 \%$ of the variation in the dependent variable can be explained by the three variables of Cost Control Effectiveness (EPB) and Working Capital Turnover (PMK) while the remaining $71 \%$ explained by other factors outside this research model. The coefficient of determination is said to be relatively small because there are $71 \%$ variations in other variables outside of this study which can explain the variation in the Price Earning Ratio (PER) variable.

\section{CONCLUSION}

This study aims to examine and analyze the effect of Cost Control Effectiveness and Working Capital Turnover on Firm Value. Sampling in this study was carried out using a data pooling technique to avoid data limitations during the eight-year observation period, namely from 2011-2018 in food and beverage sector manufacturing companies listed on the Indonesia Stock Exchange.

Based on the data analysis and discussion, the following conclusions can be drawn: Cost Control Effectiveness (EPB) has a negative and significant effect on firm value. Working Capital Turnover (PMK) has a positive and significant effect on firm value. Whie, the Effectiveness of Cost Control and Working Capital Turnover has simultaneously positive and significant effect on Firm Value.

\section{REFERENCES}

Dendawijaya, L. (2013). Manajemen Perbankan Edisi (2nd ed.). Ghalia Indonesia.

Djaja, I. (2017). All About Corporate Valuation: Memetakan, Menciptakan, Mengukur, dan Merealisasikan Nilai Perusahaan. PT. Gramedia.

Kasmir. (2018). Analisis Laporan Keuangan (11th ed.). Rajawali Pers.

Makmur. (2013). Efektivitas Kelembagaan Pengawasan. Refika Aditama.

Mulyadi. (2013). Sistem Informasi Akuntansi. BPFE.

Sedarmayanti. (2016). Sedarmayanti. 2016. Manajemen Sumber Daya Manusia Reformasi Birokrasi Dan Manajemen Pegawai Negeri Sipil. Bandung: PT. Refika Aditama. In Refika Aditama.

Sugiyono. (2013). Metode Penelitian Pendidikan Pendekatan Kuantitaif, Kualitatif, dan R\&D. 